\title{
The EPH/Ephrin System in Colorectal Cancer
}

\author{
Stavros P. Papadakos ${ }^{\dagger}$, Leonidas Petrogiannopoulos ${ }^{\dagger}$, Alexandros Pergaris (D) and Stamatios Theocharis * \\ First Department of Pathology, Medical School, National and Kapodistrian University of Athens, \\ 15772 Athens, Greece; stavrospapadakos@gmail.com (S.P.P.); lpetrogiannopoulos@gmail.com (L.P.); \\ alexperg@yahoo.com (A.P.) \\ * Correspondence: stamtheo@med.uoa.gr; Tel.: +30-210-7462116; Fax: +30-210-7456259 \\ + These authors contributed equally to this work.
}

\begin{abstract}
The EPH/ephrin system constitutes a bidirectional signaling pathway comprised of a family of tyrosine kinase receptors in tandem with their plasma membrane-bound ligand (ephrins). Its significance in a wide variety of physiologic and pathologic processes has been recognized during the past decades. In carcinogenesis, EPH/ephrins coordinate a wide spectrum of pathologic processes, such as angiogenesis, vessel infiltration, and metastasis. Despite the recent advances in colorectal cancer (CRC) diagnosis and treatment, it remains a leading cause of death globally, accounting for $9.2 \%$ of all cancer deaths. A growing body of literature has been published lately revitalizing our scientific interest towards the role of EPH/ephrins in pathogenesis and the treatment of CRC. The aim of the present review is to present the recent CRC data which might lead to clinical practice changes in the future.
\end{abstract}

Keywords: EPHs; ephrins; colon cancer; biomarkers; diagnosis; prognosis; therapy

\section{Introduction}

Citation: Papadakos, S.P.;

Petrogiannopoulos, L.; Pergaris, A.;

Theocharis, S. The EPH/Ephrin

System in Colorectal Cancer. Int. J.

Mol. Sci. 2022, 23, 2761. https://

doi.org/10.3390/ijms23052761

Academic Editors: Maurizio Battino and Takuji Tanaka

Received: 31 December 2021

Accepted: 27 February 2022

Published: 2 March 2022

Publisher's Note: MDPI stays neutral with regard to jurisdictional claims in published maps and institutional affiliations.

Copyright: (C) 2022 by the authors. Licensee MDPI, Basel, Switzerland. This article is an open access article distributed under the terms and conditions of the Creative Commons Attribution (CC BY) license (https:// creativecommons.org/licenses/by/ $4.0 /)$.

\subsection{The EPH/Ephrin System}

The EPH/ephrin signaling system is part of the broad group of tyrosine kinases, acting as regulators of a wide variety of physiologic processes (axon guidance, angiogenesis, embryologic development of intestinal epithelium). Knowledge of its contribution to carcinogenesis has emerged during the past decade [1-3]. Its function has lately been exploited extensively. Gastrulation and somitogenesis are orchestrated by members of the $\mathrm{EPH} /$ ephrin signaling pathway, highlighting its fundamental importance for the canonical early morphogenesis [4], while our interest on the normal placental development has been recently renewed due to its substantial contribution [5]. The EPH/ephrin system, given its influence in the lymphocytic maturation in thymus (the EPHB2/ephrin-B1/B2 signaling organizes the thymic medulla [6]) and in the generation of germinal centers [7], has been utilized as a treatment target in a diverse spectrum of inflammatory diseases [8]. In intestinal inflammation, the inhibition of EPHB/ephrin-B forward signaling through EPHB4 or EphB1-Fc in murine models which stimulate the Th1 cells relieves the inflammatory responses [9]. In bone marrow, the EPHB4/ephrin-B2 signaling pathway drives the maturation of erythroid progenitor cells [10] and mobilizes the hematopoietic stem and progenitor cells (HSPCs) into circulation [11]. In parallel, its impact in every step of carcinogenesis has been increasingly documented $[1,12,13]$. It has even been proposed as a potential treatment target for COVID-19 infection [14].

All the above highlight the concern regarding the orderly operation of this signaling network. Nine EPHAs and five EPHBs binding invariably five glycosylphosphatidylinositol (GPI)-anchored ephrin-A-ligands and three transmembrane ephrin-B ligands, respectively, have been documented. An emphatic characteristic of $\mathrm{EPH} /$ ephrin signaling is its bidirectional nature. The onward signaling is mediated by the EPH kinase activity in the 
EPH-expressing cells while the backward signaling in the ligand-expressing cells is mediated by the Src kinase family [15]. The bidirectional signaling is the principal trigger of the EPH-ephrin complex endocytosis, converting the adhesive interaction into a cell-to-cell repulsive response [16], which is fundamental for many physiologic processes [17]. For example, the abundance and the composition of a cell's aggregation into ephrin-B1 can influence the transition between epithelial and mesenchymal phenotypes through regulating of the cell-cell junctions $[18,19]$. Apart from the endocytosis of EPHs or their ephrins, phosphatase-dependent dephosphorylation and peptide cleavage by enzymatic hydrolysis constitute mechanisms that regulate the recycling of EPH components in the plasma membrane [20]. A growing body of literature has also analyzed the contradictory, in a multitude of instances, contribution of EPH-ephrin signaling in colorectal carcinogenesis [21,22], further indicating the immense sophistication of the aforementioned signaling system.

\subsection{The EPH/Ephrin System in Colon Tissue Formation and Physiology}

The EPH-ephrin signaling system is fundamental for the establishment of the cryptvillous axis and the location arrangement of the cellular populations. The progenitor cells populate the bottleneck of the crypt, stem cells and Paneth cells reside in the bottom of the crypt, and differentiated ones inhabit the villi. The underlying, regulatory mechanism that governs the process is the expression gradient of EPHBs and ephrins in the crypt-villous compartment. Sine qua non, EPHB2 and EPHB3 are maximally expressed in cells that reside in the lowest part of the crypt. Their expression declines ascendingly, while the expression of ephrin-B1 and ephrin-B2 has the exact opposite trajectory. It is maximal in the top of the villi and declines towards the crypt [20]. Over and above the effects of EPHB signaling in the gut's epithelium architecture, EPHBs regulate the proliferation of the intestinal stem cells via the EPHB-kinase-dependent signaling pathway [23]. Analogously, gradients in the gene expression of the EPHA family have been reported. The EPHA1, EPHA4, and EPHA7 genes are principally expressed in the crypts while the EPHA2, EPHA5, and the EFNA1 coding genes are abundantly expressed on the villi. Nevertheless, the whole spectrum of the implications of this gradient in the structure and the maintenance of the gut epithelium is still lacking [11]. These are illustrated roughly in Figure 1.

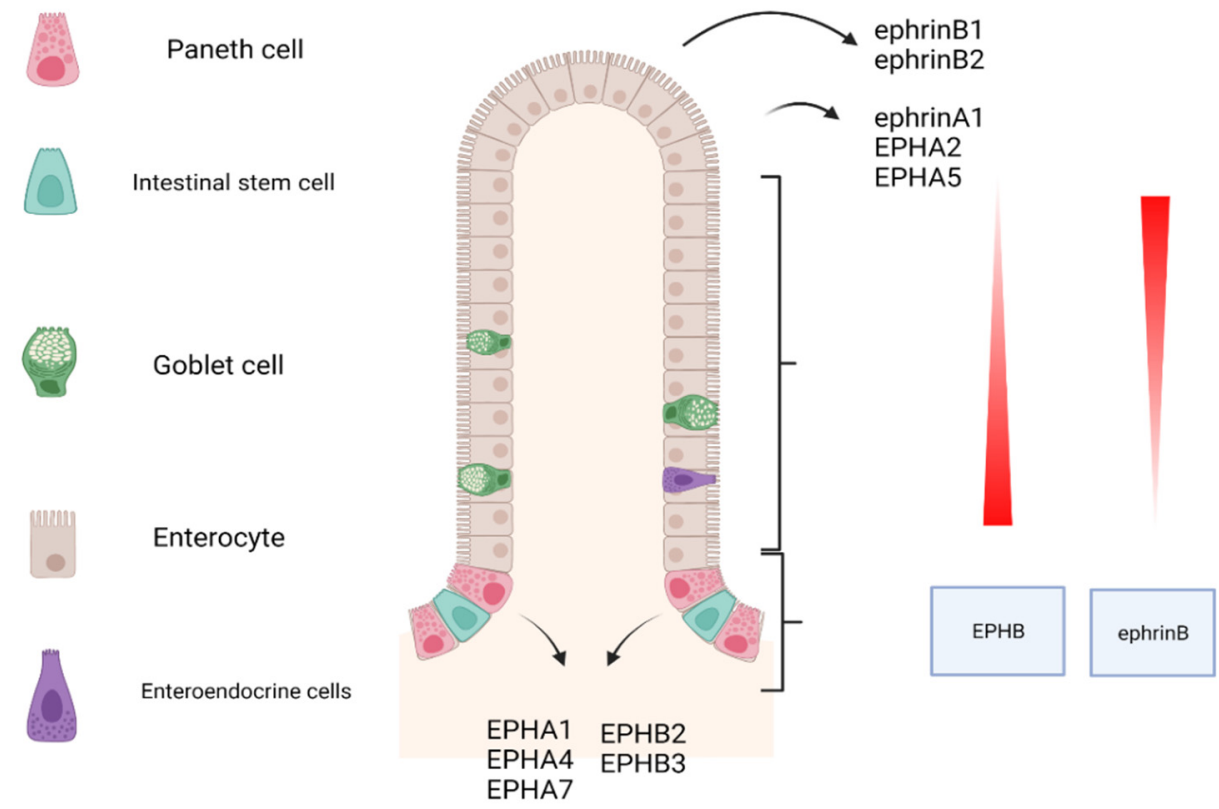

Figure 1. EPH/ephrin expression gradient in gastrointestinal tract. Black arrows: the points of maximal expression. Created with BioRender.com, accessed on 20 February 2022. 


\subsection{The Molecular Pathways of the EPH/Ephrin System}

Activation by a ligand triggers the initiation of the EPH's intracytoplasmic region RTK activity, which in turn activates molecular cascades that further transmit the signal, a process called forward signaling. GTPases of the Rho and Ras family, focal adhesion kinase (FAK), and the pathways of the Janus kinase (JAK)-signal transducer and activator of transcription (STAT), as well as the phosphoinositide 3-kinase (PI3K), have been observed to participate in forward signaling. EPH-ephrin signaling is bidirectional, as a response is also triggered in the ephrin-expressing cell [24]. The latter process is termed reverse signaling, with proteins such as Src Homology 2 (SH2) or PDZ domain containing proteins, such as Grb4, participating in order to further convey the signal [25-27]. The processes of forward and reverse signaling as well as some of the main molecular pathways implicated in them are presented in Figure 2.

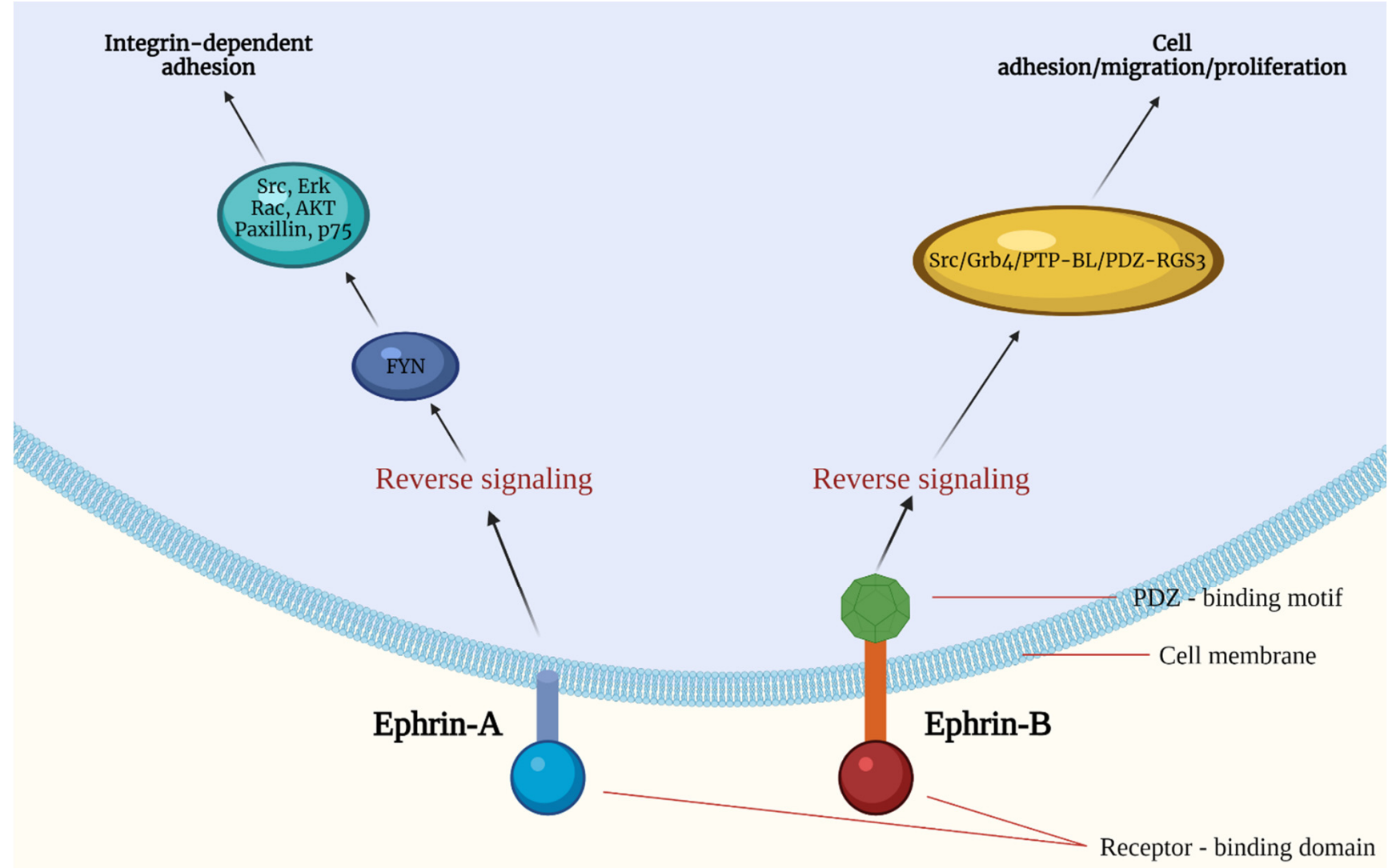

(a)

Figure 2. Cont. 


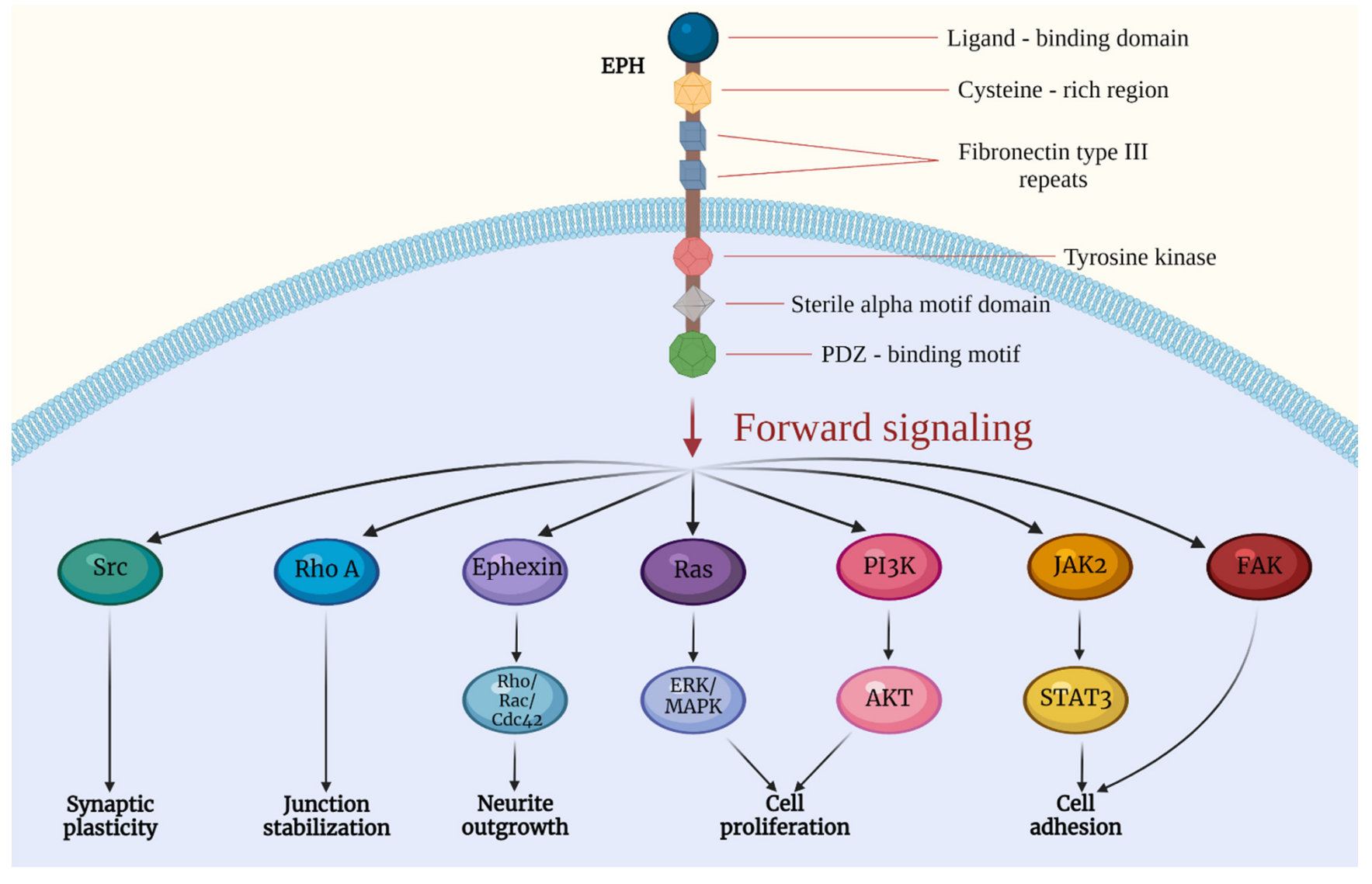

(b)

Figure 2. A response is triggered in both the ephrin-expressing cell (a) and the EPH-bearing one (b). Following EPH-ephrin interaction, an action is triggered in both cells through complex molecular mechanisms, as EPHs/ephrins interact with various molecular cascades to further convey the message into the cytoplasm. Forward signaling includes interaction of EPHs with the Src family kinases, resulting in the regulation of synapses formation, with Rho GTPases leading to junction stabilization as well as interaction with Ephexins and the ERK/MAPK pathway leading to cell proliferation. Moreover, EPHs interact with FAK and the JAK/STAT pathway, resulting in modulation of cell adhesion. Mechanisms implicated in reverse signaling include, among others, interaction between ephrins and Src, Erk, Rac, AKT, paxillin, and p75, leading to integrin-dependent cell adhesion as well as with Src, Grb4, PTP-BL, and PDZ-RGS3, regulating various actions such as cell adhesion, migration, and proliferation. PI3K: Phosphoinositide 3-kinase, JAK: Janus kinase, MAP: mitogenactivated protein, RGS3: regulator of G-protein signaling 3, FAK: focal adhesion kinase, STAT: signal transducer and activator of transcription. Created with BioRender.com, accessed on 20 February 2022.

\subsection{Colorectal Carcinoma}

Colorectal carcinoma (CRC) is the third most commonly diagnosed cancer in both sexes and, despite the extensive research in diagnostics and treatment, it still constitutes the second most fatal malignancy. An epidemiologic dichotomy among developed and transitioning countries with an approximately ten-fold variance in their incidences is documented. Well-recognized risk factors include, among others, the shift towards a more sedentary way of living with the consequent rising wave of obesity and a diet enriched in animal proteins and fats and deprived of whole grain and fibers [28]. The contribution of the genetic component in the development of disease is also largely established. In fact, the role of EPH/ephrin genetics has begun to unfold, with limited results until now. Although four variants of the EPHB2 gene (I361V, R568W, D861N, R80H) have been reported in Finnish and British populations, none of them conferred a predisposition to developing 
CRC [29]. In the same direction, the rs9520090, which constitutes a single-nucleotide polymorphism (SNP) of the EPHB2 gene, seems to affect the OS rather than affecting the development of CRC due to its role in angiogenesis [30]. Finally, the mutation burden of the EPHs occur mainly at late stages of the disease, concerning principally fibronectin type III and the tyrosine kinase [31].

\section{Molecular and Biological Relevance of EPH/Ephrin in CRC Models}

The EPHA2-ephrin-A1 interplay is of critical importance for eschewing contactinhibition. In spheroid cultures of HT-29 cells, in which the maximal cell-cell contact is applied, the downregulation of ephrin-A1 resulted in a mitigation of growth rate, interfering with the tyrosine phosphorylation of EPHA2, E-cadherin, and b-catenin, as indicated by their hyperphosphorylation under the influence of EFNA1-Fc [32]. Eriksson O. et al. demonstrated that EPHA2 and tissue factor (TF) are synchronously expressed in CRC surgical specimens. In the MDA-MB-231 breast cancer cell line, the factor VII (FVII) which is a ligand of tissue factor (TF), was shown to enhance the ephrin-A1-mediated activation of the RhoA/ROCK signaling pathway irrespective of PAR-2, inducing a "mesenchymalto-amoeboid" transformation which could be a metastasis-potentiating event [33]. In the same direction, Li M. et al. documented, in EPHA3-overexpressing cells grafted into nude mice models, the upregulation of expression of certain mRNAs and lncRNAs which are implicated in cytosolic DNA-scavenging in MAPK, VEGF, and transcription signaling pathways as well as in apoptosis and in the downregulation of specific genes that are involved in the metabolism of the conditionally essential amino acids arginine and proline, apoptosis, and cytoskeleton rearrangement [34]. Collectively, according to Li M. et al., EPHA3 regulates several signaling pathways contributing to CRC development. These results are contradictory with the documentation of Andretta E. et al. According to the latter, the overexpression of wild-type EPHA3 in LS174T and DLD1 colon cancer cell lines in parallel with the overexpression of ephrin-A5, its preferred ligand, did not have any influence on cell growth and motility or on their metastatic capacity in vivo. Analogously, the upregulation and the downregulation of mutant EPHA3 expression did not exhibit any impact on cell growth and motility, while silencing of EPHA3 neither triggered carcinogenesis nor altered the tumor size of established intestinal tumors. Overall, they downplayed the contribution of EPHA3 signaling in colorectal carcinogenesis [13].

Initial reports concerning the expression of EPHB2, EPHB3, EPHB4, and ephrin-B2 mRNA document significant alterations in the expression patterns among cancerous colonic cancer cells lines, surgical specimens, and the contiguous healthy tissue, with ephrin-B2 being the most variably expressed [35]. According to epigenetic studies in twenty-two CRC cell lines, the promoters of the abovementioned EPHs are unmethylated [36]. EPHB2 is activated by the b-catenin/TCF signaling pathway. Larriba M. et al. demonstrated that 1,25(OH)2D3 inactivates the expression of the EPHB2 gene, which can be reversed by Snail1 [37]. Chiou S.T. et al. documented, in the HT-29 cell line, that the upregulation of EPHB3 expression induced growth retardation and apoptosis. The highly EPHB3expressing cells had an epithelial appearance (tense cell-cell junctions) which became more evident in comparison with the more mesenchymal-like control cells, while confocal microscopy rendered perceptible the accumulation of E-cadherin, F-actin, and b-catenin in the cells' plasma membrane. The end-result is that EPHB3 signaling promotes tumorsuppressive processes [38]. The Apc ${ }^{\mathrm{Min} /+}$ mice have a non-functional Apc (adenomatous polyposis coli) protein due to the existence of the MIN (multiple intestinal neoplasia) allele which encodes a nonsense mutation at codon 850 [39]. These animals are genetically inclined to form tens of adenomas in the small intestine and dysplastic crypts in the colon, accumulating b-catenin in their nucleus and upregulating the expression of the EPHB2, EPHB3, and EPHB4 genes. These render them ideal models to study the initiation and progression of CRC carcinogenesis [39,40]. Battle E. et al. investigated, in Apc $\mathrm{Min}^{\mathrm{M} /+}$ mice, the effects of EPHB2 and EPHB3 expression in CRC by creating mutant receptors lacking their cytoplasmic tail. DcyEPHB2 $\mathrm{Apc}^{\mathrm{Min} /+}$ mice had ten times the number of 
tumors in the distal colon with a profoundly more invasive phenotype, as indicated by the desmoplastic reaction, in comparison with the controls. In EphB3 ${ }^{-/-} ; \mathrm{Apc}^{\mathrm{Min} /+}$ mice, they documented $30 \%$ more colorectal tumors, a two-fold increase in tumor size $>5 \mathrm{~mm}$ in diameter, and a three-fold increase in the percentage of invasive disease in comparison with $\mathrm{EphB3}^{+/-} \mathrm{Apc}^{\mathrm{Min} /+}$. The differences among $\mathrm{EPHB}^{-/-} \mathrm{Apc}^{\mathrm{Min} /+}$ and $\mathrm{EPHB}^{+/+} \mathrm{Apc}^{\mathrm{Min} /+}$ more emphatically highlight the contribution of EPHBs' downregulation in disease progression [40]. Lv J. et al. also investigated the effect of EPHB4 in carcinogenesis in vivo. They established xenograft mice from SW480 CRC cell lines and modified SW480 cell lines to over(SW480/EPHB4) and under-express (SW480/shEPHB4) the EPHB4. The SW480/EPHB4 mice had an increased growth rate and exhibited a vascular- and muscle-invasive phenotype in comparison with SW480/shEPHB4 and the controls, which indicates that EPHB4 might contribute to tumor progression and metastatic spread [41]. Still, the intensification of vascular density in conjunction with the noteworthy downregulation of E-cadherin expression in tight junctions are suggestive of the abovementioned hypothesis [41].

Taking it a step further, Yekkala K. et al. explored the contribution of c-myc signaling in CRC carcinogenesis utilizing Apc $\mathrm{Ain}^{++}$mice. They reported that $\mathrm{Apc}^{\mathrm{Min} /+} \mathrm{c}-\mathrm{myc}^{+/-}$ mice had less small intestine tumors and colon polyps with a smaller diameter than

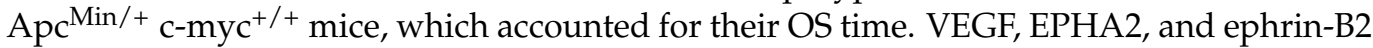
had a significant downregulation of their expression correlating with the c-myc expression levels in the small intestinal tumors [42]. Dominguez-Brauer C. et al. further investigated the role of c-myc by studying Mule, an E3 ubiquitin ligase. They documented that the knockout of Mule in APC ${ }^{\text {Min }}$ mice resulted in a nearly ten-fold increase in the number of small and large intestinal adenomas populated by cells from the bottom of the crypts due to Wnt signaling hyperactivation. Summarizing a series of more sophisticated experiments, they suggested that the loss of Mule, which orchestrates the lysosomal and proteosomal degradation of various molecules, leads to the ectopic overexpression of EPHB3 and the aberrant c-myc-mediated expression of Paneth cells and stem cells. The end result constituted the formation of the abovementioned adenoma [43].

Ephrin-B1 and ephrin-B2 are preferentially incorporated in CRC-derived exosomes [44] while only ephrin-B2 is variably expressed among exosomes derived from SW480 (primary site) and SW620 (LN metastasis) cell lines [45]. Such results indicate that the exosomal ephrin-B1 and ephrin-B2 could serve as diagnostic biomarkers. The loss of ephrin-B1 expression leads to the formation of villous adenomas. $\mathrm{Cdx} 1$ and $\mathrm{Cdx} 2$ are transcription factors necessary for the intestinal epithelium homeostasis. In human CRC specimens, the downregulation of $\mathrm{Cdx} 2$ expression is indicative of more aggressive disease, while $\mathrm{Cdx1}: \mathrm{Cdx2}: \mathrm{APC}^{\mathrm{Min}}$ mice are inclined to develop highly invasive, villus neoplasms with reduced ephrin-B1 expression [46]. Zhu Y. et al. reported that Cdx-2 promotes Notch signaling by binding in the promoter of the Dll1 gene and upregulating the ephrin-B1 expression on the adjacent cells [47]. As mentioned above, ephrin-B2 is aberrantly expressed in CRC tissues compared with the bordering normal ones [35]. Liu W. et al., taking it a step further, explored the effects of ephrin-B2 overexpression through transfection of the KM12L4 colon cancer cell line. The ephrin-B2-overexpressing mice had a significantly shrunken tumor volume, comprising approximately $25 \%$ of the tumor volume of the control mice on day 15. Further exploration with 51Cr-labelled RBCs demonstrated a decrease in the tumor blood volume, despite the generation of a tumor vascular network, due to morphologic abnormalities (e.g., thin-walled vessels). Apoptosis, along with the expression of cell cycle regulatory proteins, remained unaltered [48]. Furthermore, ephrin-B2 is linked with the generation of drug resistance in gain-of-function mutant p53 disease. Alan S.K. et al. documented that ephrin-B2 is being upregulated in response to DNA damage by recruitment of the mutated p53. Drug resistance can be attributed to a multitude of underlying molecular mechanisms. They have demonstrated that there is a JNK-mediated expression of the ATP-binding cassette transporter (ABCG2) after the activation of ephrinB2 reverse signaling. Apart from this, ephrin-B2's reverse signaling after 5-fluorouracil treatment potentiates carcinogenesis and EMT by promoting the Src-ERK and the Src-FAK 
signaling pathways, respectively [49]. The data regarding the role of the EPH/ephrin system in colorectal carcinogenesis, as reported from studies that incorporated cell lines and xenografts, are presented in Table 1.

Table 1. EPHs/ephrins studied in cell lines and xenografts, methods utilized, and results conducted.

\begin{tabular}{|c|c|c|c|c|}
\hline EPHs/Ephrins & Cell Lines/Xenografts & Methods & Outcomes & Refs. \\
\hline \multirow{5}{*}{ EPHA2 } & \multirow{2}{*}{ HT-29 cell line } & \multirow{2}{*}{ Immunoblotting, spheroid cultures } & $\begin{array}{l}\text { Ephrin-A1 influences EPHA2 } \\
\text { tyrosine phosphorylation: }\end{array}$ & \multirow{2}{*}{ [50] } \\
\hline & & & $\begin{array}{l}\text { - Reduced ephrin-A1 mitigates } \\
\text { cell proliferation }\end{array}$ & \\
\hline & MB-231 breast cancer cell line & $\begin{array}{l}\text { Proximity ligation assay, } \\
\text { confocal microscopy }\end{array}$ & $\begin{array}{l}\text { Coexpression of EPHA2 and tissue factor: } \\
\text { - } \quad \text { FVIIa potentiates the ephrin-A1-mediated, } \\
\text { PAR-2-independent RhoA/ROCK activation }\end{array}$ & {$[33]$} \\
\hline & & & $\begin{array}{l}\text { VEGF/EPHA2/ephrin-B2 pathway } \\
\text { downregulation: }\end{array}$ & \\
\hline & $\begin{array}{c}\mathrm{Apc}^{\mathrm{Min} /+} \mathrm{c}-\mathrm{myc}^{+/-} \text {mice, } \mathrm{Apc}^{\mathrm{Min} /+} \\
\mathrm{c}-\mathrm{myc}^{+/+} \text {mice }\end{array}$ & $\begin{array}{l}\text { Cell proliferation analysis, RT-PCR, cell } \\
\text { death detection in situ }\end{array}$ & $\begin{array}{l}\text { - Less small intestine tumors and colon } \\
\text { polyps with smaller diameter in } \mathrm{Apc}^{\mathrm{Min} /+} \\
{\mathrm{c}-\mathrm{myc}^{+/-} \text {mice }}^{\text {- }} \text { Better OS (of mice) }\end{array}$ & [42] \\
\hline \multirow{2}{*}{ ЕРНА3 } & $\begin{array}{l}\text { IMCE-neo, EPHA3-T37K cells/nude } \\
\text { mouse xenograft model }\end{array}$ & $\begin{array}{l}\text { IHC, cell cultures, RT-PCR, } \\
\text { Western blot }\end{array}$ & EPHA3 potentiates carcinogenesis & {$[34]$} \\
\hline & $\begin{array}{l}\text { LS174T, DLD1 colon cancer cell } \\
\text { lines/NOD/SCID, Apc }{ }^{\text {Min/+ }} \text { mice }\end{array}$ & $\begin{array}{c}\text { RNA extraction, RT-PCR, Western } \\
\text { blot, IHC }\end{array}$ & $\begin{array}{l}\text { EPHA3 has no influence on tumor initiation, } \\
\text { proliferation, and metastasis }\end{array}$ & {$[13]$} \\
\hline \multirow{3}{*}{ ЕРНВ2 } & 13 MSS and 9 MSI cell lines & $\begin{array}{l}\text { MSP, RNA extraction, sqRT-PCR, } \\
\text { Northern blot, cell cultures }\end{array}$ & Rarely promoter hypermethylation & [36] \\
\hline & SW480 cells & $\begin{array}{l}\text { Western blot, IHC, RT-PCR, } \\
\text { cell cultures }\end{array}$ & $\begin{array}{l}\text { 1,25(OH)2D3 downregulates the expression } \\
\text { of EPHB2 }\end{array}$ & {$[37]$} \\
\hline & DcyEPHB2; Apc ${ }^{\mathrm{Min} /+}$ mice & $\begin{array}{l}\text { Cell culture, Northern blot, in situ } \\
\text { hybridization, mice }\end{array}$ & $\begin{array}{l}\text { b-Catenin/Tcf4 complex target-Wnt signaling: } \\
\text { - } \quad \text { More distal colon tumors with more } \\
\text { invasive phenotype }\end{array}$ & {$[40]$} \\
\hline \multirow{4}{*}{ ЕРHB3 } & 13 MSS and 9 MSI cell lines & $\begin{array}{l}\text { MSP, RNA extraction, sqRT-PCR, } \\
\text { Northern blot, cell cultures }\end{array}$ & $\begin{array}{l}\text { Rarely promoter hypermethylation, with Snail1 } \\
\text { repressing this effect }\end{array}$ & {$[36]$} \\
\hline & $\mathrm{EPHB}^{-/-} ; \mathrm{Apc}^{\mathrm{Min} /+}$ mice & $\begin{array}{l}\text { Cell culture, Northern blot, in situ } \\
\text { hybridization, mice }\end{array}$ & $\begin{array}{l}\text { b-Catenin/Tcf } 4 \text { complex signaling } \\
\text { - } \quad \text { More colorectal tumors with increased } \\
\text { tumor size and more invasive disease }\end{array}$ & [40] \\
\hline & HT-29 cell line & $\begin{array}{c}\text { Cell culture, transwell migration assay, } \\
\text { cell aggregationassay, apoptosis } \\
\text { detection assay }\end{array}$ & $\begin{array}{l}\text { EPHB3 overexpression induced } \\
\text { - } \quad \text { growth retardation and apoptosis } \\
\text { an epithelial phenotype }\end{array}$ & {$[38]$} \\
\hline & Mule knockout $\mathrm{APC}^{\mathrm{Min}}$ mice & $\begin{array}{l}\text { Whole-exome sequencing, organoids, } \\
\text { RT-PCR, immunoblotting }\end{array}$ & Mule exerts immunosupressive functions & {$[43]$} \\
\hline \multirow[b]{2}{*}{ ЕРНВ4 } & 13 MSS and 9 MSI cell lines & $\begin{array}{l}\text { MSP, RNA extraction, sqRT-PCR, } \\
\text { Northern blot, cell cultures }\end{array}$ & Rarely promoter hypermethylation & [36] \\
\hline & $\begin{array}{l}\text { SW480 colon cancer cell lines / female } \\
\text { Balb/C athymic mice }\end{array}$ & Cell cultures, mice, tumor MVD, IHC & $\begin{array}{l}\text { EPHB4 enhances } \\
\text { - } \quad \text { tumor growth } \\
\text { - } \quad \text { metastasis }\end{array}$ & {$[41]$} \\
\hline \multirow{4}{*}{ ephrin-B1 } & $\begin{array}{l}\text { LIM1215 human colon tumor } \\
\text { cell line }\end{array}$ & $\begin{array}{l}\text { Cell culture, Western blot, } \\
\text { immunoaffinity capture }\end{array}$ & $\begin{array}{l}\text { Ephrin-B1 is incorporated in } \\
\text { CRC-derived exosomes }\end{array}$ & {$[44]$} \\
\hline & & & Reduced ephrin-B1 expression & \\
\hline & $\mathrm{Cd} 1 \mathrm{1}: \mathrm{Cd} 2 \mathrm{2}: \mathrm{APC}^{\mathrm{Min}}$ mice & & $\begin{array}{l}\text { - } \quad \text { Cdx2 knockout is responsible for highly } \\
\text { invasive, villus neoplasms }\end{array}$ & {$[46]$} \\
\hline & $\begin{array}{c}\text { SW480 cells, } \\
\text { Cdx1:Cdx2:APC }{ }^{\text {Min }} \text { mice }\end{array}$ & $\begin{array}{l}\text { Western blot, IHC, RT-PCR, cell } \\
\text { cultures, chromatin } \\
\text { immunoprecipitation }\end{array}$ & $\begin{array}{l}\text { Ephrin-B1 gene beingin Notch-regulated: } \\
\text { Enhanced generation of polyps in intestinal tract }\end{array}$ & [47] \\
\hline
\end{tabular}


Table 1. Cont.

\begin{tabular}{|c|c|c|c|c|}
\hline EPHs/Ephrins & Cell Lines/Xenografts & Methods & Outcomes & Refs. \\
\hline \multirow{4}{*}{ ephrin-B2 } & $\begin{array}{l}\text { LIM1215 human colon tumor } \\
\text { cell line }\end{array}$ & $\begin{array}{l}\text { Cell culture, Western blot, } \\
\text { immunoaffinity capture }\end{array}$ & $\begin{array}{l}\text { Ephrin-B2 is incorporated in } \\
\text { CRC-derived exosomes }\end{array}$ & [44] \\
\hline & $\begin{array}{c}\mathrm{Apc}^{\mathrm{Min} /+} \mathrm{c}-\mathrm{myc}^{+/-} \text {mice, } \mathrm{Apc}^{\mathrm{Min} /+} \\
\mathrm{c}-\mathrm{myc}^{+/+} \text {mice }\end{array}$ & $\begin{array}{c}\text { Cell proliferation analysis, RT-PCR, cell } \\
\text { death detection in situ }\end{array}$ & $\begin{array}{l}\text { VEGF/EPHA2/ephrin-B2 } \\
\text { significantly downregulated } \\
\text { - } \quad \text { Less small intestine tumors and colon } \\
\text { polyps with smaller diameter in } \mathrm{Apc}^{\mathrm{Min} /+} \\
\text { c-myc } \mathrm{mice}^{+/-} \text {mice } \\
\text { - Better OS (in mice) }\end{array}$ & [42] \\
\hline & $\begin{array}{l}\text { SW480 primary, SW620 metastatic } \\
\text { human colorectal cancer cell lines }\end{array}$ & $\begin{array}{l}\text { Cell culture, Western blot, } \\
\text { immunoaffinity capture }\end{array}$ & $\begin{array}{l}\text { Ephrin-B2 is overexpressed in } \\
\text { SW620-derived exosomes }\end{array}$ & [45] \\
\hline & $\begin{array}{l}\text { KM12L4 colon cancer cell } \\
\text { line/ephrin-B2-overexpressing mice }\end{array}$ & Cell cultures, mice, IHC, Northern blot & $\begin{array}{l}\text { - } \quad \text { Significantly shrunken tumor volume } \\
\text { Morphologic abnormalities in tumor } \\
\text { vascular network }\end{array}$ & [48] \\
\hline
\end{tabular}

\section{Prognostic and Predictive Role of the EPH/Ephrin System in CRC}

The contribution of EPH/ephrin signaling in the developmental process of embryonic vasculature is well-established in the literature, constituting the foundations for the conceptualization of EPH/ephrin involvement in tumor neovascularization. Oqawa K. et al., experimenting with xenografts from human-derived breast cancer and Kaposi's sarcoma cell lines, documented the expression of ephrin-A1 and EPHA2 all over the endothelial lining and cancer cells, demonstrating analogous results in surgically resected CRC specimens [51]. It is common knowledge now that certain EPHAs (EPHA1, EPHA2, EPHA8) and EPHBs (EPHB2, EPHB4) are variably expressed in CRC [52-54] specimens, compared with the adjacent normal intestinal tissues, with their expression further being downregulated with CRC progression [54].

The downregulation of EPHA1 is suggestive of lower overall survival (OS) [55], in accordance with the poorer progression-free survival (PFS) in patients with elevated EPHA2 expression [56]. The expression of EPHA2 also heralds a weak response in anti-EGFR therapy [56-58]. Li M. et al. reported a statistically significant association between EPHA3 expression and CRC grade of differentiation and lymph node (LN) infiltration, which triggered a series of experiments/studies with cell lines and xenografts [34]. In contrast to the aforementioned data, Andretta E. et al. did not report any association between clinicopathological parameters and EPHA3 expression [13]. The EPHA4 immunohistochemical (IHC) expression was correlated with patients' age, tumor size, depth of invasion, LN status, and the TNM Classification of Malignant Tumors (TNM) stage. Its increased expression was also indicative of poor prognosis [59].

According to Laiho P. et al., EPHBs exhibit a significant variance in their expression among serrated and typical CRC tissues, possibly contributing to the pathogenesis of disease [57]. EPHB2 expression is associated with improved prognosis and better recurrence-free survival (RFS) and OS, as indicated by a multitude of clinical trials [60-62]. Similarly, EPHB3 positive staining was associated with better OS and RFS. Additionally, EPHB3 expression was reported to be higher in CRC tissues compared with the adjacent normal mucosa and its expression was noted as downregulated during the conversion from adenoma to carcinoma [62]. Chiu S.T. et al., analyzing data from patients with advanced CRC, demonstrated a noteworthy downregulation of EPHB3 expression [38], while Ulivi P. et al. demonstrated that EPHB4 was substantially overexpressed in the lessinflammatory, right-sided tumors in comparison with their left-sided counterparts [63]. In accordance with the latter, Lv J.H. et al. reported the upregulation of EPHB4 expression in CRC tissues while ephrin-B2 remained unaltered [41].

Epigenetic mechanisms also contribute to colorectal carcinogenesis; namely, miR-645 downregulating the ephrin-A5 mRNA influences tumor growth and metastasis [64]. Finally, patients who do not respond well to neoadjuvant therapy tend to have higher ephrin-B2 expression than the responders [49].

The abovementioned data are documented in detail in Table 2. 
Table 2. EPHs/ephrins studied in patients' tissues, methods utilized, and results conducted.

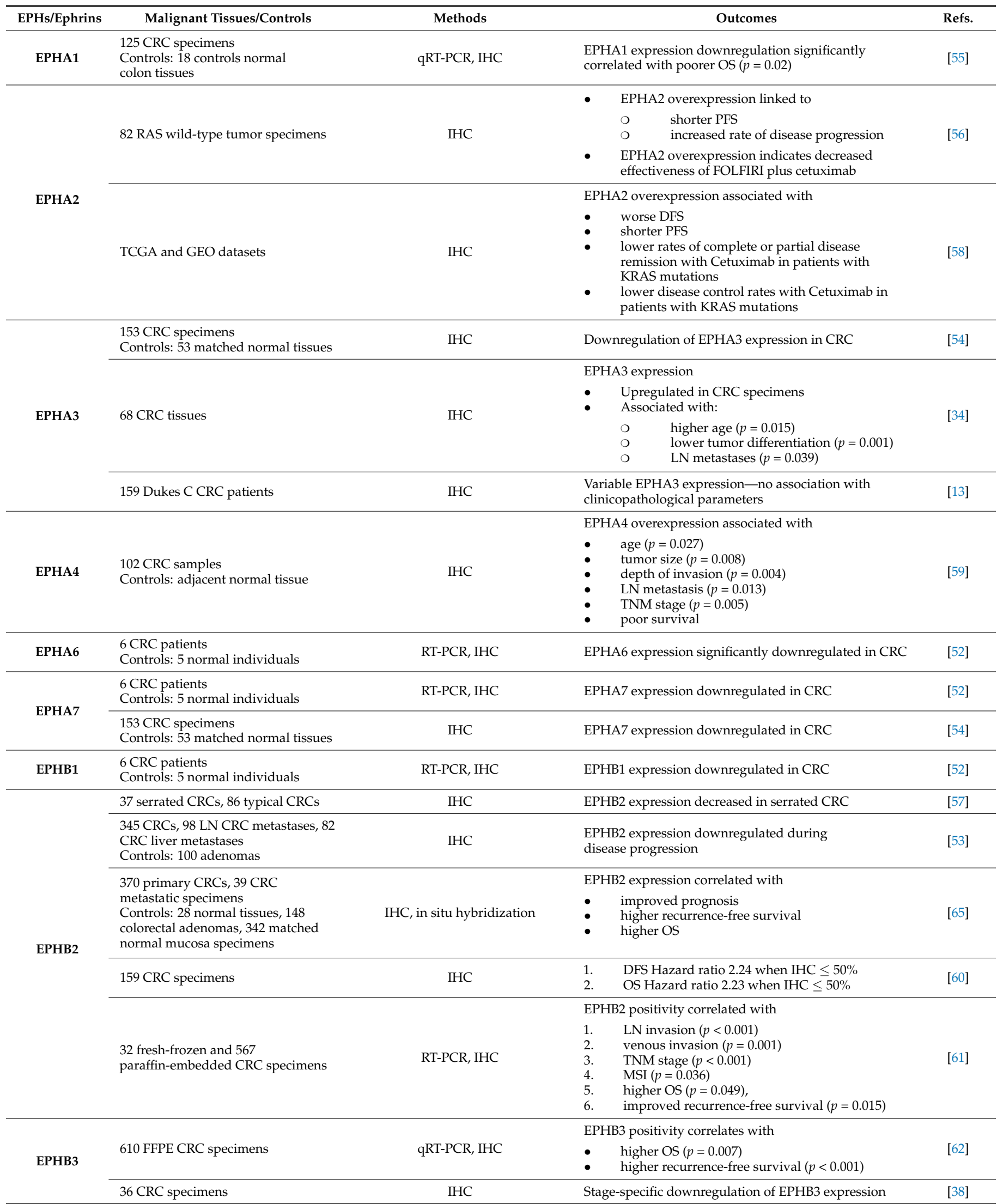


Table 2. Cont.

\begin{tabular}{|c|c|c|c|c|}
\hline EPHs/Ephrins & Malignant Tissues/Controls & Methods & Outcomes & Refs. \\
\hline \multirow[t]{2}{*}{ EPHB4 } & $\begin{array}{l}60 \text { specimens from patients } \\
\text { that received chemotherapy } \\
(\mathrm{CT})+\text { bevacizumab (B) and } \\
62 \text { specimens from patients } \\
\text { treated with CT alone } \\
51 \text { right-sided and } 71 \\
\text { left-sided tumor specimens }\end{array}$ & IHC & $\begin{array}{l}\text { 1. } \begin{array}{l}\text { EPHB4 expression elevated in } \\
\text { right-sided tumors }\end{array} \\
\text { 2. Better OS, PFS for right-sided tumors with } \mathrm{CT}+\mathrm{B}\end{array}$ & [63] \\
\hline & $\begin{array}{l}200 \text { CRC specimens } \\
\text { Controls: } 50 \text { paired normal } \\
\text { mucosa specimens }\end{array}$ & IHC & Upregulation of EPHB4 expression in CRC tissues & [41] \\
\hline ephrin-A5 & 28 CRC specimens & RT-PCR, IHC & $\begin{array}{l}\text { Decreased ephrin-A5 expression enhances } \\
\text { - tumor proliferation } \\
\text { - tumor invasion }\end{array}$ & {$[64]$} \\
\hline ephrin-B2 & $\begin{array}{l}250 \text { CRC specimens } \\
\text { Controls: } 50 \text { paired normal } \\
\text { mucosa specimens }\end{array}$ & IHC & $\begin{array}{l}\text { Ephrin-B2 expression unaltered between } \mathrm{CRC} \text { and } \\
\text { normal tissues }\end{array}$ & [41] \\
\hline & 21 CRC specimens & IHC & $\begin{array}{l}\text { Ephrin-B2 expression increased in neo-adjuvant } \\
\text { treatment non-responders }\end{array}$ & [49] \\
\hline
\end{tabular}

The various roles of the EPH/ephrin system in CRC carcinogenesis are presented in Figure 3.

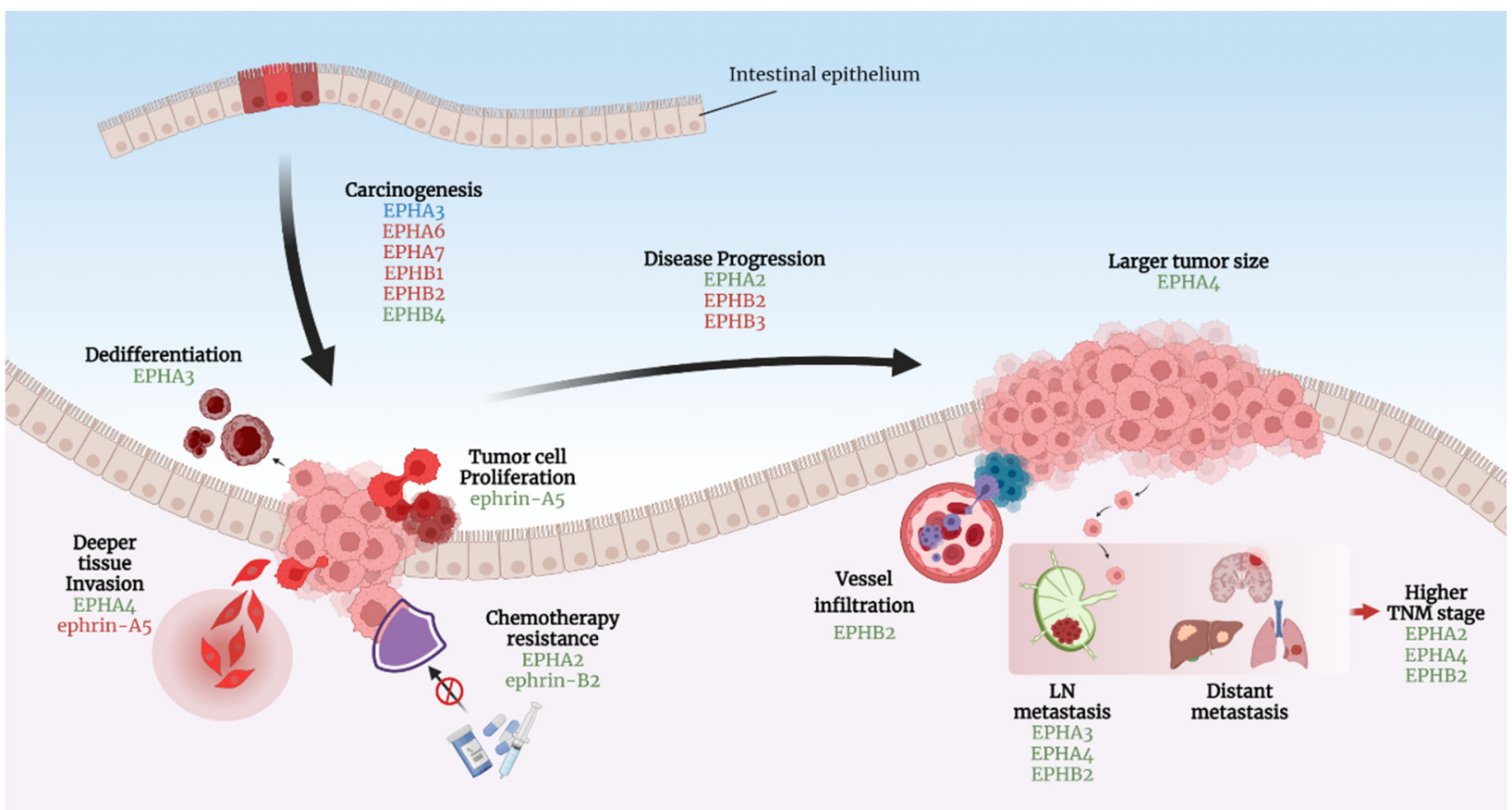

Figure 3. EPHs/ephrins can either enhance or suppress CRC carcinogenesis in various steps. Green fonts: EPHs/ephrins promoting the specific process. Red fonts: EPHs/ephrins inhibit each described action. Blue fonts: Contradictory results have been reported regarding the role of EPHA3 in CRC carcinogenesis. Created with BioRender.com, accessed on 20 February 2022.

\section{The EPH/Ephrin System as a Treatment Target in CRC}

Although several approaches to therapeutically target the EPH/ephrin system have been developed, currently clinical studies regarding the CRC do not exist. Any detailed narration is beyond the scope of this text and has been done elsewhere [66,67], and only the basic principles will be presented here. The basic therapeutic applications of the $\mathrm{EPH} /$ ephrin system include EPH-targeting antibodies, recombinant proteins blocking the EPH-ephrin interaction, peptides carrying chemotherapeutics, and EPH kinase inhibitors [66]. With respect to CRC, the main body of literature consists of preclinical data. 
Concurrently, the introduction of new systemic therapeutic options such as biologics (antiEGFR, anti-VEGF drugs), immunotherapy, BRAF-targeting drugs, MEK inhibitors, and salvage agents enriched our therapeutic reservoir while deepening our perception of CRC biology, especially on the differences between right- and left-sided tumors, comprising a valuable source of prognostic and predictive data [68]. Despite those advancements, there are still gaps in our therapeutic approach that could be addressed, and targeting of the $\mathrm{EPH} /$ ephrin system could come forward as a therapeutic perspective.

Chemotherapeutics (e.g., capecitabine, oxaliplatin, and irinotecan) have constituted the mainstay of therapeutic options in the systemic treatment of CRC. Their clinical utility has been extended from high-risk stage II disease (e.g., T4 disease, low differentiation) to stage III surgically resected tumors as an adjuvant treatment. In conjunction with biologic agents, chemotherapeutics exhibit notable efficiency in the management of metastatic disease [68]. Their unfavorable side-effects profile, which frequently are additive with therapeutic combinations of fluoropyrimidines with oxaliplatin, comprise a main weakness. The dilemma becomes more challenging when extensive accumulative doses are needed [69]. Towards this direction, attempts to target EPHB2 with monoclonal antibodies (Mab) have been made. $2 \mathrm{H} 9$ blocks the interaction between EPHB2 and ephrins, inhibiting the activation of EPHB and impeding the downstream signaling cascade. The conjugation of monomethyl auristatin E(MMAE)with Mab 2H9 restricted the tumor volume of MMAE-vc-2H9-treated xenograft mice (from HT1080-GD and CXF1103 human colon cancer lines), while a four- to ten-fold enhancement in tumor volume was documented in the vehicle-treated mice. This highlights its in vivo clinical effectiveness, which should be further examined in human clinical trials [70]. Formononetin, a natural phytoestrogen extract, showed encouraging results in reducing SW1116 and HCT116 human CRC cell lines growth and migration in a dose-dependent manner. These effects are the end result of a plethora of cellular mechanisms such as the cell cycle arrest in the G0-G1 phase, the downregulation of cyclinD1, the inhibition of matrix metalloproteinase 2(MMP2) and matrix metalloproteinase 9(MMP9), and the upregulation of miR-149. miR-149 causes subsequent cellular growth reduction by EPHB3 downregulation. The principal mediating signaling processes are the inactivation of the PI3K/Akt pathway and the STAT3 phosphorylation [71]. The importance of the EPHB-triggered signaling cascade to support the proliferation of CRC cells has been extensively documented. NVP-Iso, an EPH-specific tyrosine kinase inhibitor (TKI), causes tumor growth retardation on mice models, inducing an autophagy-mediated cell death [72]. The major advantages from the utilization of those agents could be derived by the elective signaling blockage of the EPH tyrosine kinase family, which could significantly limit their side-effects profile. Collectively, the abovementioned agents target distinct cellular pathways and could possibly complement the currently used treatment protocols.

Another therapeutic contribution might be the enhancement of sensitivity of established therapeutic agents. The introduction of anti-EGFR agents has improved the outcomes of CRC patients. Characteristically, the combination of chemotherapy plus an anti-EGFR agent exerts its superiority over the combination of chemotherapy plus an anti-VEGF. These effects are more emphatic in the left-sided tumors over the right-sided ones, highlighting their biologic differences [73]. The mutation analysis of RAS and RAF status is of paramount importance, since any downstream mutations can affect the responsiveness to biologics $[74,75]$. The stimulation of the EPHA2 signaling pathway stimulated the efficacy of cetuximab in patients with NRAS activating mutations and metastatic disease. Metastatic CRC disease with wild-type KRAS status and activating NRAS mutations did not exhibit a clinical benefit from EGFR blocking. Despite the fact that EPHA1 was activated when $\mathrm{NRAS}^{+/+}$cells were exposed to cetuximab and EPHA2 was significantly downregulated, the expression of the EPHA2 gene in $\mathrm{NRAS}^{\mathrm{Q} 61 \mathrm{~K} /{ }^{+}}$cells remained unaffected, indicating a functional relationship among the EPHA2 and EGFR [76]. Furthermore, the drug resistance mechanisms in mutant p53 CRC via ephrin-B2 reverse signaling are thoroughly mentioned above. An approach to target ephrin-B2 as a means to enhance the therapeutic efficacy of DNA-damaging cytotoxic chemotherapeutics could be of therapeutic value [49]. 
Finally, miR-149 has been documented to act directly on the TGFB2 gene and regulates cellular proliferation and the sensitivity to 5-fluorouracil (5-FU) [77]. The documentation of miR-149-mimickers' effectiveness in clinical trials would be of decisive importance, as they could be an invaluable part of our therapeutic artillery against CRC, reducing the toxicity from systemic chemotherapy.

Metastasis represents a significant cause of mortality in CRC patients. The current therapeutic approach includes the use of chemotherapy in conjunction with biologics [68]. Ephrin-A1 heralds a poor prognosis for CRC patients. Ieguchi K. et al. demonstrated in HEK293 cells that the ADAM-12-cleaved ephrin-A1 (ephrin-A1 174R) phosphorylated the EPHA2 and dephosphorylated Akt comparably with ephrin-A1-Fc while inducing defects in cells' motility. In xenograft models, the treatment with KB-R7785, which is an ADAM inhibitor, induced an apoptosis-mediated growth retardation and significantly less metastatic burden. The implicated mechanisms were the concomitantly downregulating specific growth factors, such as HB-EGF and IGF [78]. This could revolutionize cancer treatment since it could offer the possibility to prevent metastatic disease. An enormous drawback for their utilization in clinical trials is their poor efficacy and side-effects profile, which are attributed to their broad spectrum of ADAM inhibition. A more targeted approach (e.g., ADAM-12 siRNA or ephrin-A1-targeting antibodies) could attain better clinical results [79]. The implicated therapeutic mechanisms are summarized in Table 3.

Table 3. Treatment of CRC through EPH/ephrin signaling.

\begin{tabular}{|c|c|c|c|c|}
\hline Drug & Cell Type/Animal model & Mechanisms & Outcomes & Refs. \\
\hline $\begin{array}{c}\text { Ephrin-A1 174R } \\
\text { (cleaved ephrin-A1) }\end{array}$ & HEK293 cells & $\begin{array}{l}\text { EPHA2 phosphorylation } \\
\text { Akt dephosphorylation }\end{array}$ & Decreased cell motility & [78] \\
\hline $\begin{array}{c}\text { KB-R7785 } \\
\text { (ADAM, MMP inhibitor) }\end{array}$ & $\begin{array}{l}\text { Tumor-bearing C57BL/6 } \\
\text { WT mice }\end{array}$ & Apoptosis induction & $\begin{array}{l}\text { Tumor growth retardation } \\
\text { Reduction of lung metastases }\end{array}$ & [78] \\
\hline Ephrin-A1 mimickers / cetuximab & NRASQ61K/+ cells & $\begin{array}{c}\text { EPHA2-mediated Akt } \\
\text { MAPK signaling } \\
\text { inhibition }\end{array}$ & $\begin{array}{c}\text { Enhancement of responsiveness } \\
\text { to cetuximab treatment }\end{array}$ & [56] \\
\hline NVP-BHG712, NVP-Iso & $\begin{array}{c}\text { EphB4+ HT-29 cells, } \\
\text { EphB2+ Colo205 } \\
\text { cells/tumor-bearing mice }\end{array}$ & $\begin{array}{l}\text { Phosphotyrosine- } \\
\text { dependent EPH } \\
\text { signaling blockage }\end{array}$ & $\begin{array}{l}\text { Autophagy stimulation } \\
\text { Decreased cell growth/ } \\
\text { tumor volume }\end{array}$ & [72] \\
\hline $\begin{array}{l}\text { MMAE-vc-2H9 (monomethyl } \\
\text { auristatin E with Mab 2H9) }\end{array}$ & $\begin{array}{l}\text { HT1080-GD, CXF1103 cell } \\
\text { lines/tumor-bearing mice }\end{array}$ & & $\begin{array}{l}\text { Decreased cell } \\
\text { proliferation/tumor } \\
\text { volume inhibition }\end{array}$ & [70] \\
\hline Formononetin & SW1116, HCT116 cell lines & $\begin{array}{l}\text { Cell cycle arrest in G0-G1 } \\
\text { phase, downregulation of } \\
\text { cyclinD1, inhibition of } \\
\text { MMP2-MMP9, } \\
\text { upregulation of miR-149 }\end{array}$ & Reduced cell growth, migration & [71] \\
\hline
\end{tabular}

\section{Conclusions}

It is evident that $\mathrm{EPH} /$ ephrin signaling has an instrumental role in CRC carcinogenesis. Currently, the genetic studies concerning EPH/ephrin signaling remain limited and have failed to demonstrate a predisposing relationship between specific gene variants and CRC [30,31]. EPHA2, EPHA3 and EPHB2, EPHB3 comprise the most well studied predictive and prognostic biomarkers during CRC progression. EPHA2 regulates cellular proliferation and the cytoskeleton and could serve as a prognostic (e.g., PFS, disease progression) and predictive biomarker of the response to cetuximab [56,58]. There are a plethora of clinical specimen data associating EPHB2 and EPHB3 expression with overall survival [43,45], highlighting their potential utilization as prognostic biomarkers. Their clinical significance has been correlated with the in vitro and in vivo analyses. The blockage of EphB2 and EphB3 signaling accelerated the carcinogenesis process [40], indicating their tumor suppressive function. Their probable clinical applicability can be categorized as follows: (a) tumor reductive agents which interact with various components of EPH/ephrin signaling; (b) carriers that target the EPH/ephrin system to deliver cytotoxic agents to 
tumor cells; (c) enhancers of the efficacy of other biologics or chemotherapeutics; and (d) anti-metastatic agents.

It is becoming evident that therapeutic interventions in the EPH/ephrin system could reshape the architecture of colorectal carcinoma treatment and their efficiency should be validated in clinical trials in humans. Further research could enlighten our unaddressed inquiries towards the molecular mechanisms that govern the EPH/ephrin signaling system in CRC carcinogenesis.

Author Contributions: Conceptualization, S.P.P. and L.P. and S.T.; methodology, S.P.P.; investigation, S.P.P. and A.P.; resources, L.P.; writing—original draft preparation, S.P.P.; writing—review and editing, S.P.P. and A.P.; visualization, A.P.; supervision, S.T.; All authors have read and agreed to the published version of the manuscript.

Funding: This research received no external funding.

Institutional Review Board Statement: Not applicable.

Informed Consent Statement: Not applicable.

Conflicts of Interest: The authors declare no conflict of interest.

$\begin{array}{ll}\text { Abbreviations } \\ \text { EPH } & \text { erythropoietin-producing human hepatocellular receptors } \\ \text { Ephrin } & \text { EPH family receptor interacting proteins } \\ \text { IHC } & \text { immunohistochemistry } \\ \text { PCR } & \text { polymerase chain reaction } \\ \text { RT-PCR } & \text { reverse transcription-polymerase chain reaction } \\ \text { q PCR } & \text { quantitative reverse transcription-polymerase chain reaction } \\ \text { LN } & \text { lymph nodes } \\ \text { OS } & \text { overall survival } \\ \text { DFS } & \text { disease-free survival } \\ \text { EMT } & \text { epithelial-mesenchymal transition } \\ \text { EGFR } & \text { epidermal growth factor receptor } \\ \text { CRC } & \text { colorectal carcinoma } \\ \text { RFS } & \text { recurrence-free survival }\end{array}$

\section{References}

1. Pergaris, A.; Danas, E.; Goutas, D.; Sykaras, A.G.; Soranidis, A.; Theocharis, S. Molecular Sciences The Clinical Impact of the EPH/Ephrin System in Cancer: Unwinding the Thread. Int. J. Mol. Sci. 2021, 22, 8412. [CrossRef] [PubMed]

2. Pasquale, E.B. Eph receptor signalling casts a wide net on cell behaviour. Nat. Rev. Mol. Cell Biol. 2005, 6, 462-475. [CrossRef] [PubMed]

3. Pasquale, E.B. EPH-ephrin Bidirectional Signaling in Physiology and Disease. Cell 2008, 133, 38-52. [CrossRef]

4. Gaitanos, T.; Dudanova, I.; Sakkou, M.; Klein, R.; Paixão, S. The Eph receptor family. In Receptor Tyrosine Kinases: Family and Subfamilies; Springer: Cham, Switzerland, 2015; pp. 165-264. ISBN 9783319118888.

5. Chatzizacharias, N.A.; Giaginis, C.T.; Agapitos, E.; Theocharis, S.E. The role of ephrins' receptors and ephrins' ligands in normal placental development and disease. Expert Opin. Ther. Targets 2014, 18, 269-275. [CrossRef]

6. Cejalvo, T.; Munoz, J.J.; Tobajas, E.; Alfaro, D.; García-Ceca, J.; Zapata, A. Conditioned deletion of ephrinB1 and/or ephrinB2 in either thymocytes or thymic epithelial cells alters the organization of thymic medulla and favors the appearance of thymic epithelial cysts. Histochem. Cell Biol. 2015, 143, 517-529. [CrossRef] [PubMed]

7. Darling, T.K.; Lamb, T.J. Emerging roles for Eph receptors and ephrin ligands in immunity. Front. Immunol. 2019, 10, 1473. [CrossRef]

8. Kim, A.; Seong, K.M.; Choi, Y.Y.; Shim, S.; Park, S.; Lee, S.S. Inhibition of epha2 by dasatinib suppresses radiation-induced intestinal injury. Int. J. Mol. Sci. 2020, 21, 9096. [CrossRef]

9. Grandi, A.; Zini, I.; Palese, S.; Giorgio, C.; Tognolini, M.; Marchesani, F.; Bruno, S.; Flammini, L.; Cantoni, A.M.; Castelli, R.; et al. Targeting the Eph/ephrin system as anti-inflammatory strategy in IBD. Front. Pharmacol. 2019, 10, 691. [CrossRef]

10. Suenobu, S.; Takakura, N.; Inada, T.; Yamada, Y.; Yuasa, H.; Zhang, X.Q.; Sakano, S.; Oike, Y.; Suda, T. A role of EphB4 receptor and its ligand, ephrin-B2, in erythropoiesis. Biochem. Biophys. Res. Commun. 2002, 293, 1124-1131. [CrossRef] 
11. Kwak, H.; Salvucci, O.; Weigert, R.; Martinez-Torrecuadrada, J.L.; Henkemeyer, M.; Poulos, M.G.; Butler, J.M.; Tosato, G. Sinusoidal ephrin receptor EPHB4 controls hematopoietic progenitor cell mobilization from bone marrow. J. Clin. Investig. 2016, 126, 4554-4568. [CrossRef]

12. Janes, P.W.; Vail, M.E.; Ernst, M.; Scott, A.M. Eph receptors in the immunosuppressive tumor microenvironment. Cancer Res. 2021, 81, 801-805. [CrossRef] [PubMed]

13. Andretta, E.; Cartón-García, F.; Martínez-Barriocanal, Á.; De Marcondes, P.G.; Jimenez-Flores, L.M.; MacAya, I.; Bazzocco, S.; Bilic, J.; Rodrigues, P.; Nieto, R.; et al. Investigation of the role of tyrosine kinase receptor EPHA3 in colorectal cancer. Sci. Rep. 2017, 7, 41576. [CrossRef] [PubMed]

14. Mendoza, R.; Saha, N.; Momeni, A.; Gabutan, E.; Alawad, M.; Dehghani, A.; Diks, J.; Lin, B.; Wang, D.; Alshal, M.; et al. Ephrin-A1 and the sheddase ADAM12 are upregulated in COVID-19. Heliyon 2021, 7, e07200. [CrossRef]

15. Pasquale, E.B. Eph receptors and ephrins in cancer: Bidirectional signalling and beyond. Nat. Rev. Cancer 2010, 10, 165-180. [CrossRef] [PubMed]

16. Zimmer, M.; Palmer, A.; Köhler, J.; Klein, R. EphB-ephrinB bi-directional endocytosis terminates adhesion allowing contact mediated repulsion. Nat. Cell Biol. 2003, 5, 869-878. [CrossRef]

17. Wilkinson, D.G. Regulation of cell differentiation by Eph receptor and ephrin signaling. Cell Adh. Migr. 2014, 8, 339-348. [CrossRef] [PubMed]

18. Lee, H.S.; Nishanian, T.G.; Mood, K.; Bong, Y.S.; Daar, I.O. EphrinB1 controls cell-cell junctions through the Par polarity complex. Nat. Cell Biol. 2008, 10, 979-986. [CrossRef]

19. Miao, H.; Wang, B. Eph/ephrin signaling in epithelial development and homeostasis. Int. J. Biochem. Cell Biol. 2009, 41, 762-770. [CrossRef]

20. White, B.E.P.; Getsios, S. Eph receptor and ephrin function in breast, gut, and skin epithelia. Cell Adhes. Migr. 2014, 8, 327-338 [CrossRef]

21. Dopeso, H.; Mateo-Lozano, S.; Mazzolini, R.; Rodrigues, P.; Lagares-Tena, L.; Ceron, J.; Romero, J.; Esteves, M.; Landolfi, S.; Hernández-Losa, J.; et al. The receptor tyrosine kinase EPHB4 has tumor suppressor activities in intestinal tumorigenesis. Cancer Res. 2009, 69, 7430-7438. [CrossRef]

22. Leroy, C.; Fialin, C.; Sirvent, A.; Simon, V.; Urbaeh, S.; Poncet, J.; Robert, B.; Jouin, P.; Roche, S. Quantitative phosphoproteomics reveals a cluster of tyrosine kinases that mediates src invasive activity in advanced colon carcinoma cells. Cancer Res. 2009, 69, 2279-2286. [CrossRef] [PubMed]

23. Holmberg, J.; Genander, M.; Halford, M.M.; Annerén, C.; Sondell, M.; Chumley, M.J.; Silvany, R.E.; Henkemeyer, M.; Frisén, J. EphB Receptors Coordinate Migration and Proliferation in the Intestinal Stem Cell Niche. Cell 2006, 125, 1151-1163. [CrossRef] [PubMed]

24. Klein, R. Eph/ephrin signaling in morphogenesis, neural development and plasticity. Curr. Opin. Cell Biol. 2004, 16, 580-589. [CrossRef] [PubMed]

25. Edwards, C.M.; Mundy, G.R. Eph receptors and ephrin signaling pathways: A role in bone homeostasis. Int. J. Med. Sci. 2008, 5, 263-272. [CrossRef] [PubMed]

26. Wan, Y.; Yang, J.S.; Xu, L.C.; Huang, X.J.; Wang, W.; Xie, M.J. Roles of Eph/ephrin bidirectional signaling during injury and recovery of the central nervous system. Neural Regen. Res. 2018, 13, 1313-1321. [CrossRef]

27. Singh, A.; Winterbottom, E.; Daar, I.O. Eph/ephrin signaling in cell-cell and cell-substrate adhesion. Front. Biosci. 2012, 17, 473-497. [CrossRef]

28. Sung, H.; Ferlay, J.; Siegel, R.L.; Laversanne, M.; Soerjomataram, I.; Jemal, A.; Bray, F. Global Cancer Statistics 2020: GLOBOCAN Estimates of Incidence and Mortality Worldwide for 36 Cancers in 185 Countries. CA. Cancer J. Clin. 2021, 71, 209-249. [CrossRef]

29. Kokko, A.; Laiho, P.; Lehtonen, R.; Korja, S.; Carvajal-Carmona, L.G.; Järvinen, H.; Mecklin, J.P.; Eng, C.; Schleutker, J.; Tomlinson, I.P.M.; et al. EPHB2 germline variants in patients with colorectal cancer or hyperplastic polyposis. BMC Cancer 2006, 6, 145 . [CrossRef]

30. Scherer, D.; Deutelmoser, H.; Balavarca, Y.; Toth, R.; Habermann, N.; Buck, K.; Kap, E.J.; Botma, A.; Seibold, P.; Jansen, L.; et al. Polymorphisms in the angiogenesis-related genes EFNB2, MMP2 and JAG1 are associated with survival of colorectal cancer patients. Int. J. Mol. Sci. 2020, 21, 5395. [CrossRef]

31. Mathot, L.; Kundu, S.; Ljungström, V.; Svedlund, J.; Moens, L.; Adlerteg, T.; Falk-Sörqvist, E.; Rendo, V.; Bellomo, C.; Mayrhofer, M.; et al. Somatic ephrin receptor mutations are associated with metastasis in primary colorectal cancer. Cancer Res. 2017, 77, 1730-1740. [CrossRef]

32. Yekkala, K.; Baudino, T.A.; Martiny-Baron, G.; Korff, T.; Schaffner, F.; Esser, N.; Eggstein, S.; Marme, D.; Augustin, H.G.; Li, S.; et al. Reduced expression of EphrinA1 (EFNA1) inhibits three-dimensional growth of HT29 colon carcinoma cells. Carcinogenesis 2007, 12, 237-243.

33. Eriksson, O.; Thulin, Å.; Asplund, A.; Hegde, G.; Navani, S.; Siegbahn, A. Cross-talk between the Tissue Factor/coagulation factor VIIa complex and the tyrosine kinase receptor EphA2 in cancer. BMC Cancer 2016, 16, 341. [CrossRef] [PubMed]

34. Li, M.; Yang, C.; Liu, X.; Yuan, L.; Zhang, F.; Wang, M.; Miao, D.; Gu, X.; Jiang, S.; Cui, B.; et al. EphA3 promotes malignant transformation of colorectal epithelial cells by upregulating oncogenic pathways. Cancer Lett. 2016, 383, 195-203. [CrossRef]

35. Liu, W.; Ahmad, S.A.; Jung, Y.D.; Reinmuth, N.; Fan, F.; Bucana, C.D.; Ellis, L.M. Coexpression of ephrin-Bs and their receptors in colon carcinoma. Cancer 2002, 94, 934-939. [CrossRef] 
36. Wu, Q.; Lind, G.E.; Aasheim, H.C.; Micci, F.; Silins, I.; Tropé, C.G.; Nesland, J.M.; Lothe, R.A.; Suo, Z. The EPH receptor Bs (EPHBs) promoters are unmethylated in colon and ovarian cancers. Epigenetics 2007, 2, 237-243. [CrossRef] [PubMed]

37. Larriba, M.J.; Valle, N.; Pálmer, H.G.; Ordóñez-Morán, P.; Álvarez-Díaz, S.; Becker, K.F.; Gamallo, C.; De Herreros, A.G.; GonzálezSancho, J.M.; Muñoz, A. The inhibition of Wnt/ $\beta$-catenin signalling by $1 \alpha, 25$-dihydroxyvitamin D3 is abrogated by Snail1 in human colon cancer cells. Endocr. Relat. Cancer 2007, 14, 141-151. [CrossRef]

38. Chiu, S.T.; Chang, K.J.; Ting, C.H.; Shen, H.C.; Li, H.; Hsieh, F.J. Over-expression of EphB3 enhances cell-cell contacts and suppresses tumor growth in HT-29 human colon cancer cells. Carcinogenesis 2009, 30, 1475-1486. [CrossRef]

39. Moser, A.R.; Luongo, C.; Gould, K.A.; McNeley, M.K.; Shoemaker, A.R.; Dove, W.F. ApcMin: A mouse model for intestinal and mammary tumorigenesis. Eur. J. Cancer 1995, 31, 1061-1064. [CrossRef]

40. Batlle, E.; Bacani, J.; Begthel, H.; Jonkeer, S.; Gregorieff, A.; Van De Born, M.; Malats, N.; Sancho, E.; Boon, E.; Pawson, T.; et al. EphB receptor activity suppresses colorectal cancer progression. Nature 2005, 435, 1126-1130. [CrossRef]

41. Lv, J.H.; Xia, Q.Y.; Wang, J.J.; Shen, Q.; Zhang, J.; Zhou, X.J. EphB4 promotes the proliferation, invasion, and angiogenesis of human colorectal cancer. Exp. Mol. Pathol. 2016, 100, 402-408. [CrossRef]

42. Yekkala, K.; Baudino, T.A. Inhibition of intestinal polyposis with reduced angiogenesis in Apc Min/+ mice due to decreases in c-Myc expression. Mol. Cancer Res. 2007, 5, 1296-1303. [CrossRef] [PubMed]

43. Dominguez-Brauer, C.; Hao, Z.; Elia, A.J.; Fortin, J.M.; Nechanitzky, R.; Brauer, P.M.; Sheng, Y.; Mana, M.D.; Chio, I.I.C.; Haight, J.; et al. Mule Regulates the Intestinal Stem Cell Niche via the Wnt Pathway and Targets EphB3 for Proteasomal and Lysosomal Degradation. Cell Stem Cell 2016, 19, 205-216. [CrossRef] [PubMed]

44. Mathivanan, S.; Lim, J.W.E.; Tauro, B.J.; Ji, H.; Moritz, R.L.; Simpson, R.J. Proteomics analysis of A33 immunoaffinity-purified exosomes released from the human colon tumor cell line LIM1215 reveals a tissue-specific protein signature. Mol. Cell. Proteom. 2010, 9, 197-208. [CrossRef] [PubMed]

45. Ji, H.; Greening, D.W.; Barnes, T.W.; Lim, J.W.; Tauro, B.J.; Rai, A.; Xu, R.; Adda, C.; Mathivanan, S.; Zhao, W.; et al. Proteome profiling of exosomes derived from human primary and metastatic colorectal cancer cells reveal differential expression of key metastatic factors and signal transduction components. Proteomics 2013, 13, 1672-1686. [CrossRef] [PubMed]

46. Hryniuk, A.; Grainger, S.; Savory, J.G.A.; Lohnes, D. Cdx1 and Cdx2 Function as tumor suppressors. J. Biol. Chem. 2014, 289, 33343-33354. [CrossRef]

47. Zhu, Y.; Hryniuk, A.; Foley, T.; Hess, B.; Lohnes, D. Cdx2 Regulates Intestinal EphrinB1 through the Notch Pathway. Genes 2021, 12, 188. [CrossRef]

48. Liu, W.; Jung, Y.D.; Ahmad, S.A.; McCarty, M.F.; Stoeltzing, O.; Reinmuth, N.; Fan, F.; Ellis, L.M. Effects of overexpression of ephrin-B2 on tumour growth in human colorectal cancer. Br. J. Cancer 2004, 90, 1620-1626. [CrossRef]

49. Alam, S.K.; Yadav, V.K.; Bajaj, S.; Datta, A.; Dutta, S.K.; Bhattacharyya, M.; Bhattacharya, S.; Debnath, S.; Roy, S.; Boardman, L.A.; et al. DNA damage-induced ephrin-B2 reverse signaling promotes chemoresistance and drives EMT in colorectal carcinoma harboring mutant p53. Cell Death Differ. 2016, 23, 707-722. [CrossRef]

50. Potla, L.; Boghaert, E.R.; Armellino, D.; Frost, P.; Damle, N.K. Reduced expression of EphrinA1 (EFNA1) inhibits three-dimensional growth of HT29 colon carcinoma cells. Cancer Lett. 2002, 175, 187-195. [CrossRef]

51. Ogawa, K.; Pasqualini, R.; Lindberg, R.A.; Kain, R.; Freeman, A.L.; Pasquale, E.B. The ephrin-A1 ligand and its receptor, EphA2, are expressed during tumor neovascularization. Oncogene 2000, 19, 6043-6052. [CrossRef]

52. Hafner, C.; Schmitz, G.; Meyer, S.; Bataille, F.; Hau, P.; Langmann, T.; Dietmaier, W.; Landthaler, M.; Vogt, T. Differential Gene Expression of Eph Receptors and Ephrins in Benign Human Tissues and Cancers. Clin. Chem. 2004, 50, 490-499. [CrossRef] [PubMed]

53. Guo, D.L.; Zhang, J.; Yuen, S.T.; Tsui, W.Y.; Chan, A.S.Y.; Ho, C.; Ji, J.; Leung, S.Y.; Chen, X. Reduced expression of EphB2 that parallels invasion and metastasis in colorectal tumours. Carcinogenesis 2006, 27, 454-464. [CrossRef] [PubMed]

54. Herath, N.I.; Spanevello, M.D.; Doecke, J.D.; Smith, F.M.; Pouponnot, C.; Boyd, A.W. Complex expression patterns of Eph receptor tyrosine kinases and their ephrin ligands in colorectal carcinogenesis. Eur. J. Cancer 2012, 48, 753-762. [CrossRef] [PubMed]

55. Herath, N.I.; Doecke, J.; Leggett, B.A.; Boyd, A.W. Epigenetic silencing of EphA1 expression in colorectal cancer is correlated with poor survival. Br. J. Cancer 2009, 100, 1095-1102. [CrossRef]

56. Martini, G.; Cardone, C.; Vitiello, P.P.; Belli, V.; Napolitano, S.; Troiani, T.; Ciardiello, D.; Della Corte, C.M.; Morgillo, F.; Matrone, N.; et al. EphA2 is a predictive biomarker of resistance and a potential therapeutic target for improving antiepidermal growth factor receptor therapy in colorectal cancer. Mol. Cancer Ther. 2019, 18, 845-855. [CrossRef]

57. Laiho, P.; Kokko, A.; Vanharanta, S.; Salovaara, R.; Sammalkorpi, H.; Järvinen, H.; Mecklin, J.P.; Karttunen, T.J.; Tuppurainen, K.; Davalos, V.; et al. Serrated carcinomas form a subclass of colorectal cancer with distinct molecular basis. Oncogene 2007, 26, 312-320. [CrossRef]

58. De Robertis, M.; Loiacono, L.; Fusilli, C.; Poeta, M.L.; Mazza, T.; Sanchez, M.; Marchionni, L.; Signori, E.; Vescovi, A.L.; Garciafoncillas, J.; et al. Dysregulation of EGFR Pathway in EphA2 Cell Subpopulation Significantly Associates with Poor Prognosis in Colorectal Cancer. Clin. Cancer Res. 2018, 23, 159-170. [CrossRef]

59. Feng, J.; Zhang, Q.; Jin, Q.; Liang, H.; Sugimura, H.; Zhang, S.; Wang, J. High expression of EphA4 is associated with invasion and lymph node metastasis in colorectal carcinomas. Int. J. Clin. Exp. Pathol. 2017, 10, 9697-9703.

60. Drucker, A.; Arnason, T.; Yan, S.R.; Aljawad, M.; Thompson, K.; Huang, W. Ephrin B2 Receptor and Microsatellite Status in Lymph Node-Positive Colon Cancer Survival 1. Transl. Oncol. 2013, 6, 520-527. [CrossRef] 
61. Jang, B.G.; Kim, H.S.; Chang, W.Y.; Bae, J.M.; Kang, G.H. Prognostic Significance of EPHB2 Expression in Colorectal Cancer Progression. J. Pathol. Transl. Med. 2018, 52, 298-306. [CrossRef]

62. Jang, B.G.; Kim, H.S.; Bae, J.M.; Kim, W.H.; Hyun, C.L.; Kang, G.H. Expression profile and prognostic significance of EPHB3 in colorectal cancer. Biomolecules 2020, 10, 602. [CrossRef] [PubMed]

63. Ulivi, P.; Scarpi, E.; Chiadini, E.; Marisi, G.; Valgiusti, M.; Capelli, L.; Casadei Gardini, A.; Monti, M.; Ruscelli, S.; Frassineti, G.L.; et al. Right- vs. left-sided metastatic colorectal cancer: Differences in tumor biology and bevacizumab efficacy. Int. J. Mol. Sci. 2017, 18, 1240. [CrossRef] [PubMed]

64. Li, S.; Hou, X.; Wu, C.; Han, L.; Li, Q.; Wang, J.; Luo, S. MiR-645 promotes invasiveness, metastasis and tumor growth in colorectal cancer by targeting EFNA5. Biomed. Pharmacother. 2020, 125, 109889. [CrossRef] [PubMed]

65. Jubb, A.M.; Zhong, F.; Bheddah, S.; Grabsch, H.I.; Frantz, G.D.; Mueller, W.; Kavi, V.; Quirke, P.; Polakis, P.; Koeppen, H. EphB2 is a prognostic factor in colorectal cancer. Clin. Cancer Res. 2005, 11, 5181-5187. [CrossRef]

66. Lodola, A.; Giorgio, C.; Incerti, M.; Zanotti, I.; Tognolini, M. European Journal of Medicinal Chemistry Targeting Eph/ephrin system in cancer therapy. Eur. J. Med. Chem. 2017, 142, 152-162. [CrossRef]

67. Barquilla, A.; Pasquale, E.B. Eph Receptors and Ephrins: Therapeutic Opportunities. Annu. Rev. Pharmacol. Toxicol. 2015, 55, 465. [CrossRef]

68. Dekker, E.; Tanis, P.J.; Vleugels, J.L.A.; Kasi, P.M.; Wallace, M.B. Colorectal cancer. Lancet 2019, 394, 1467-1480. [CrossRef]

69. Hertz, D.L.; Dockter, T.J.; Satele, D.V.; Loprinzi, C.L.; Le-Rademacher, J. Neuropathy severity at the time of oxaliplatin treatment alteration in patients with colon cancer (Alliance A151912). Support. Care Cancer 2021, 29, 7855-7863. [CrossRef]

70. Mao, W.; Luis, E.; Ross, S.; Silva, J.; Tan, C.; Crowley, C.; Chui, C.; Franz, G.; Senter, P.; Koeppen, H.; et al. EphB2 as a therapeutic antibody drug target for the treatment of colorectal cancer. Cancer Res. 2004, 64, 781-788. [CrossRef]

71. Wang, A.L.; Li, Y.; Zhao, Q.; Fan, L.Q. Formononetin inhibits colon carcinoma cell growth and invasion by microRNA-149mediated EphB3 downregulation and inhibition of PI3K/AKT and STAT3 signaling pathways. Mol. Med. Rep. 2018, 17, 7721-7729. [CrossRef]

72. DiPrima, M.; Wang, D.; Tröster, A.; Maric, D.; Terrades-Garcia, N.; Ha, T.; Kwak, H.; Sanchez-Martin, D.; Kudlinzki, D.; Schwalbe, $\mathrm{H}$.; et al. Identification of Eph receptor signaling as a regulator of autophagy and a therapeutic target in colorectal carcinoma. Mol. Oncol. 2019, 13, 2441-2459. [CrossRef] [PubMed]

73. Arnold, D.; Lueza, B.; Douillard, J.Y.; Peeters, M.; Lenz, H.J.; Venook, A.; Heinemann, V.; Van Cutsem, E.; Pignon, J.P.; Tabernero, J.; et al. Prognostic and predictive value of primary tumour side in patients with RAS wild-type metastatic colorectal cancer treated with chemotherapy and EGFR directed antibodies in six randomized trials. Ann. Oncol. Off. J. Eur. Soc. Med. Oncol. 2017, 28, 1713-1729. [CrossRef] [PubMed]

74. Heinemann, V.; von Weikersthal, L.F.; Decker, T.; Kiani, A.; Vehling-Kaiser, U.; Al-Batran, S.-E.; Heintges, T.; Lerchenmüller, C.; Kahl, C.; Seipelt, G.; et al. FOLFIRI plus cetuximab versus FOLFIRI plus bevacizumab as first-line treatment for patients with metastatic colorectal cancer (FIRE-3): A randomised, open-label, phase 3 trial. Lancet Oncol. 2014, 15, 1065-1075. [CrossRef]

75. Van Cutsem, E.; Köhne, C.H.; Láng, I.; Folprecht, G.; Nowacki, M.P.; Cascinu, S.; Shchepotin, I.; Maurel, J.; Cunningham, D.; Tejpar, S.; et al. Cetuximab plus irinotecan, fluorouracil, and leucovorin as first-line treatment for metastatic colorectal cancer: Updated analysis of overall survival according to tumor KRAS and BRAF mutation status. J. Clin. Oncol. 2011, 29, $2011-2019$. [CrossRef] [PubMed]

76. Cuyàs, E.; Queralt, B.; Martin-Castillo, B.; Bosch-Barrera, J.; Menendez, J.A. EphA2 receptor activation with ephrin-A1 ligand restores cetuximab efficacy in NRAS-mutant colorectal cancer cells. Oncol. Rep. 2017, 38, 263-270. [CrossRef]

77. Qu, L.; Chen, Y.; Zhang, F.; He, L. The lncRNA DLGAP1-AS1/miR-149-5p/TGFB2 axis contributes to colorectal cancer progression and 5-FU resistance by regulating smad2 pathway. Mol. Ther. Oncolyt. 2021, 20, 607-624. [CrossRef] [PubMed]

78. Ieguchi, K.; Tomita, T.; Takao, T.; Omori, T.; Mishima, T.; Shimizu, I.; Tognolini, M.; Lodola, A.; Tsunoda, T.; Kobayashi, S.; et al. Analysis of adam12-mediated ephrin-a1 cleavage and its biological functions. Int. J. Mol. Sci. 2021, 22, 2480. [CrossRef]

79. Ieguchi, K.; Maru, Y. Savior or not: ADAM17 inhibitors overcome radiotherapy-resistance in non-small cell lung cancer. J. Thorac. Dis. 2016, 8, E813. [CrossRef] 